\title{
Resensi
}

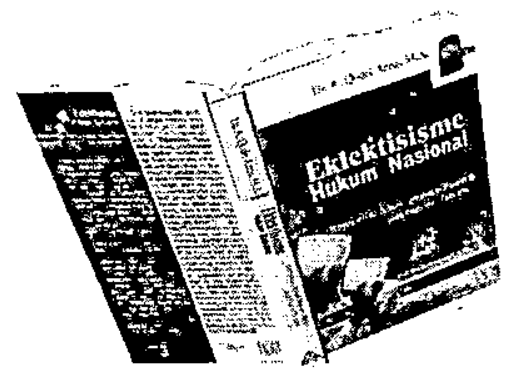

Judul

: Eklektisisme Hukum Nasional: Kompetisi Antara Hukum Islam dan Hukum Umum

Penulis

: Dr. A. Qodri Azizy, MA.

Cetakan

Penerbit

Tebal Buku

ISBN

: Pertama, Februari 2002

: Gama Media, Yogyakarta

: XXIV + 260 Halaman $14 \times 20 \mathrm{~cm}$

: $979-9552-17-6$

\section{Positivisasi Hukum Islam di Indonesia}

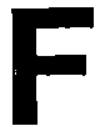

enomena kegelisahan intelektual muncul ketika terjadi dikotomi tajam antara istilah "Hukum Islam" dan "Hukum Umum" yang identik dengan "hukum positif". Sehingga menimbulkan posisi saling berhadapan "hukum Islam versus hukum umum" atau "hukum Islam versus hukum positif". Dikotomi ini semakin parah ketika kemudian mempunyai wilayah masing-masing. Anggapan yang ada selama ini, bahwa "hukum Islam" mempunyai wilayah bernama Fakultas Syari'ah, sedangkan "hukum umum" mempunyai wilayah bernama Fakultas Hukum. Tidak heran jika hukum umum diidentikkan dengan hukum Belanda; sementara hukum Islam atau fiqih diidentikkan dengan wahyu Allah yang mutlak dan suci meskipun merupakan hasil ijtihad fuqaha empat belas tahun lalu di negara Arab.

Memang disadari ada istilah "Hukum Adat" yang juga diajarkan baik di Fakultas Syari'ah maupun Fakultas Hukum. Namun hukum adat dimaksud sarat dengan nuansa politik peninggalan Belanda, sehingga tidak sama dengan hukum kebiasaan (customary (aw) atau hukum yang hidup di masyarakat (iving law), meskipun ada pihak yang berusaha menyamakannya atau setidaknya memahaminya demikian.

Realitas di atas mengindikasikan, bahwa selama ini telah terjadi "salah kaprah" (misleading) dalam memahami hukum Islam, terlebih di saat membandingkan atau meletakkan posisi yang proporsional antara hukum Islam atau fiqh dengan hukum umum. Padahal menurut A. Qodri Azizy (selanjutnya penulis) sistem hukum Indonesia atau hukum nasional mempunyai perbedaan yang sangat fundamental dengan sistem hukum Belanda (HIm: XIII).

Setelah masa reformasi, dengan dilegitimasi oleh GBHN 1999, hukum Islam mempunyai posisi yang sangat jelas. Namun perlu ada pemahaman yang tepat mengenai hukum Islam atau fiqih yang tidak selalu identik dengan syari'ah atau wahyu Allah. Setelah tumbangnya rezim Orde Baru, secara teoritis kondisi Indonesia memasuki era demokratisasi, meskipun kini masih dalam transisi dan sering tampak masih dalam batas retorika politik. Namun nilai-nilai masyarakat termasuk nilai global akan lebih mempunyai keleluasaan untuk masuk ke dalam sistem sosial negara Indonesia. Dalam waktu yang sama nilai-nilai agama termasuk hukum agama juga 
mempunyai kesempatan lebih luas dibanding dengan pada masa sebelumnya. Hal ini mencakup perkembangan pembinaan hukum nasional. Sebagai konsekuensinya, perkembangan hukum nasional akan mencakup tiga elemen sumber hukum yang mempunyai kedudukan sama dan seimbang, yaitu hukum Adat (lebih tepatnya "hukum kebiasaan"), hukum dari barat (bermula dari hukum Belanda) dan hukum Islam.

Dalam rangka menjawab persoalanpersoalan yang muncul di tengah-tengah pembinaan hukum nasional, penulis menghadirkan buku dengan judul "Eklektisisme Hukum Nasionaf". Konsep yang diberikan penulis amat kontributif dalam rangka memberikan jalan terwujudnya hukum nasional yang telah lama dicitacitakan. Pada bagian prolog buku ini, Busthanul Arifin mendefinisikan eklektisisme ialah suatu sistem (agama atau filsafat) yang dibentuk secara kritis memilih dari berbagai sumber dan doktrin (HIm. VIII). Lebih lanjut penulis buku ini bermaksud membentuk hukum nasional Indonesia dengan secara kritis memilih unsur-unsur dari doktrin hukum yang memang berlaku di Indonesia.

\section{Konsep Eklektisisme Hukum Nasional}

Buku yang ditulis A. Qodri Azizy berisi tiga bagian pembahasan dan satu bagian kesimpulan. Bagian pertama mendeskripsikan "Hukum Islam:definisi, spesifikasi dan posisinya dalam IImu Hukum". Pada bagian ini penulis membahas secara rinci tentang definisi Hukum Islam yang sering dijumpai kerancuan dengan istilah figh yang merupakan hasil ijtihad ulama di satu sisi dengan konsep syariah Allah yang identik dengan wahyu yang absolut (HIm:47).
Selain memperjelas istilah, esensi dan posisi antara hukum Islam yang identik dengan fiqh di satu sisi dan Syari'ah (wahyu Allah) di sisi lain, penulis secara rinci membahas fiqh sebagai ilmu hukum Islam (Islamic jurisprudence) yang mempunyai peluang ijtihad dalam pembaharuan hukum Islam, penulis juga memposisikan antara hukum Islam dan hukum umum (HIm: 87).

Bagian kedua menjelaskan "Kedudukan Hukum Islam di Indonesia: Sekilas Sejarahnya". Selain dibahas tentang sistem hukum yang berlaku di Indonesia yaitu, a) hukum adat yang muncul dari pluralitas jenis penduduknya, b) hukum Islam yang datang ke Indonesia bersamaan dengan hadirnya agama, dan c) sistem hukum Belanda atau sistem hukum barat (Civil law), dalam rangka mengarah kepada proses eklektisisme, penulis juga membahas pembinaan hukum nasional yang meliputi arah dan sasaran pembangunan hukum nasional. Menurut penulis (HIm: 129-130), terdapat catatan dari semua hasil seminar Hukum Nasional baik di masa Orde Lama, Orde Baru maupun Orde Reformasi bahwa, $\mathrm{P}$ e $\mathrm{m}$ b i $\mathrm{n}$ a a $\mathrm{n}$ hukum nasional mengarah pada pembentukan sebuah hukum nasional yang berupa kodifikasi dan unifikasi - meskipun tetap mengakui keberadaan hukum tidak tertulis - serta mampu menjamin kepastian hukum.

Pada bagian ketiga diberi mengelaborasi "Positivisasi Hukum Isiam: Realisasi GBHN 1999" (HIm: 171). Sebenarnya bagian ke tiga merupakan inti dari pembahasan buku ini. GBHN tahun 1999 merupakan kelanjutan dari dan sekaligus koreksi terhadap perkembangan sebelumnya, maka arah kebijakan hukum nasional setelah GBHN 1999 ini mempunyai spesifikasi yang tidak dapat didapatkan pada sebelum GBHN 1999. GBHN ini semakin mempertegas keberadaan hukum Islam, yang merupakan salah satu hukum Agama, sebagai salah satu dari tiga 
bahan baku hukum nasional. Dua yang lainnya adalah hukum Adat dan hukum Belanda, dalam pengertian dinamis, yakni hukum negara maju.

Bila dibaca dengan cermat sebetulnya tema pokok buku ini lebih tepat "POSITIVISASI HUKUM ISLAM DI INDONESIA". Apabila penulis konsisten dengan judul "Eklektisisme Hukum Nasional" adalah membentuk hukum nasional dengan secara kritis memilih dari berbagai sumber dan doktrin hukum yang berlaku di Indonesia, maka dalam hal ini seharusnya penulis membahas dan mengkritisi tiga sistem hukum yang berlaku di Indonesia yaitu hukum Islam, hukum adat dan hukum Barat yang ketiganya mempunyai peluang sama sebagai bahan baku hukum nasional. Secara proporsional, seharusnya penulis mengkritisi nilai-nilai atau prinsip-prinsip hukum yang dapat diambil dari ketiga sistem hukum yang hidup di Indonesia. Tetapi buku ini didominasi oleh pembahasan hukum Islam dan hukum barat yang diakhiri dengan pengusulan positivisasi hukum Islam sebagai salah satu bahan hukum nasional. Pembahasan tentang hukum adat yang oleh penulis lebih tepat disebut dengan hukum kebiasaan (Customary law) atau hukum yang hidup di masyarakat (living law) hanya ditampilkan sekilas (HIm: 109, 111, 235, 236).

Pada bagian kesimpulan bukan hanya mengemukakan alur dan jalur yang tepat dilalui fiqih (hukum Islam) dalam jajaran sumber ilmu hukum tetapi merekomendasikan pula alur dan jalur yang dapat dimasuki oleh hukum barat dan hukum adat (Customary law dan living law). Sehingga akan didapatkan eklektisisme hukum Nasional yang komprehensif. Oleh karena itu dalam rangka penyempumaan, pada edisi revisi perlu ditampilkan pembahasan yang rinci dan proporsional dari ketiga sistem hukum yang berpeluang sebagai bahan baku pembentukan hukum Nasional. Dalam rangka reformasi hukum di Indonesia, penulis telah menyampaikan konsep eklektisisme hukum dalam wacana nasional, walaupun pada cover buku ini penulis memberi catatan tentang kompetisi antara hukum islam dan hukum umum. Hal ini menunjukkan penulis tampaknya menguasai kedua bidang hukum yaitu hukum Islam dan hukum Barat (HIm: VII).

Berbeda dengan kebanyakan penulis buku tentang hukum Islam yang lain, yang biasa menggunakan pendekatan deduktif dan sarat dengan dalil, maka penulis buku ini lebih banyak menitikberatkan penggunaan pendekatan deskriptif analitik dan empirik atau induktif. Selain itu dilengkapi juga dengan pendekatan komparatif serta analisis argumentatif. Dengan beberapa pendekatan tersebut penulis mengajak kepada para pembaca agar menjadikan buku ini, sebagai bahan yang hidup, yang memotivasi untuk berdiskusi dengan kritis dan argumentatif.

Dalam rangka reformasi hukum di Indonesia, buku ini penulis menawarkan enam jalur yang sangat efektif untuk dipertimbangkan bagi para praktisi hukum, para akademisi dan para pembuatundang-undang ketika menyusun rencana hukum nasional yang bersifat kodifikatif dan unifikatif:

1. Jalur peraturan perundang-undangan, fiqh dapat berperan baik sebagai hukum materiil (esensi hukum) ataupun fiqh dalam konteks etikal moralitas hukum. Sehingga kitab-kitab yang membahas fiqh dapat diposisikan sebagai recht book di satu sisi, dan isinya dapat diposisikan sebagai doktrin atau pendapat ahli hukum.

2. Sumber kebijakan pelaksanaan pemerintahan dalam konteks kedisiplinan administratif, yang berkaitan 
dengan nilai-nilai legislasi.

3. Jalur jurisprudence, figh dapat secara legal formal dijadikan landasan dan pertimbangan hakim untuk memberi putusan hakim.

4. Sumber bagi penegak hukum, polisi, jaksa dan pengacara.

5. Sumber ilmu hukum atau filsafat hukum (jurisprudence atau philosophy of law).

6. Sumber nilai-nilai budaya masyarakat dan sekaligus sebagai sumber kebiasaan (Customary law atau living law) (HIm:250-251).

Kehadiran reformasi total di Indonesia menjadi kesempatan sekaligus tantangan bagi kajian hukum Indonesia. Sehingga hukum dapat membumi dalam rangka menjawab persoalan-persoalan kemanusiaan. Konsekuensinya adalah peningkatan kualitas pelaku kajian dan orientasi model dan pendekatan kajian hukum Islam di lembaga-lembaga akademik. Oleh karena itu isi buku ini dapat diterima pembacanya dengan cermat, kritis dan argumentatif ( $\mathrm{HIm}$ XVIII). Sebagai suatu bentuk kontribusi anak bangsa kepada pengembangan wacana hukum nasional buku ini sangat baik dan penting untuk dibaca oleh para akademisi dan praktisi di Indonesia, terutama peminat studi hukum.

Rahmani Timorita Yulianti 